\title{
Design of Resources Monitoring and Controlling System on Aircraft Maintenance Project in XYZ MRO
}

\author{
Yendy Rachmatulloh ${ }^{1}$ and Raden Venantius Hari Ginardi ${ }^{2}$ \\ ${ }^{1}$ Department of Management Technology, Institut Teknologi Sepuluh Nopember, Surabaya \\ ${ }^{2}$ Department of Information Technology, Institut Teknologi Sepuluh Nopember, Surabaya \\ e-mail : hari.ginardi@gmail.com
}

\begin{abstract}
Maintenance Repair and Overhaul (MRO) XYZ is a company engaged in aviation / aviation, especially in aircraft maintenance. MRO XYZ can work on the maintenance of several types of aircraft and its components in accordance with the certification and permits owned by MRO XYZ. The vital aspects that must be regulated in an aircraft maintenance project include the engineer involved in the maintenance process and the manhours calculation system who must be able to explain every detail of the work on an aircraft maintenance project. In addition, other resources such as consumbale material and raw material must also be monitored and controlled, so that management team can obtain COGS as optimal as possible in the project and profitability can increase. This research was built to provide solutions to the aircraft maintenance process stakeholders in meeting vital information needs that must be continuously monitored and based on this information, the system built will be able to control the ongoing maintenance process of the aircraft, in accordance with regulations.
\end{abstract}

Keywords-Aircraft Maintenance, MRO, Monitoring and Controlling System.

\section{INTRODUCTION}

$\mathrm{T}$ EE development of Information Technology (IT) in various sectors, especially aviation, has become an integral part of business objectives. Management-organized business plans require IT support. The importance of IT's role in supporting business processes on aircraft maintenance is considered for the standardization and certification process of companies engaged in aviation and aerospace. This led to the importance of IT implementation, especially in aviation companies, especially the Aircraft Maintenance Division (Maintenance Repair \& Overhaul/MRO).

Aircraft maintenance is an important part of the business process in the aviation company in general. The aviation company must have a special division that handles all the aircraft maintenance processes, and there is also an aviation company that is specialized in aircraft maintenance only, commonly referred to as MRO. Examples of MRO in Indonesia are Garuda Maintenance Facility (GMF AeroAsia) and Merpati Maintenance Facility (MMF), and there are several other smaller MRO scales [2-4].

The business process that occurs in aircraft maintenance can differ and be specific to any MRO, but in general they follow the rules and standards stipulated by the Indonesian Government (through the Ministry of Transportation) and

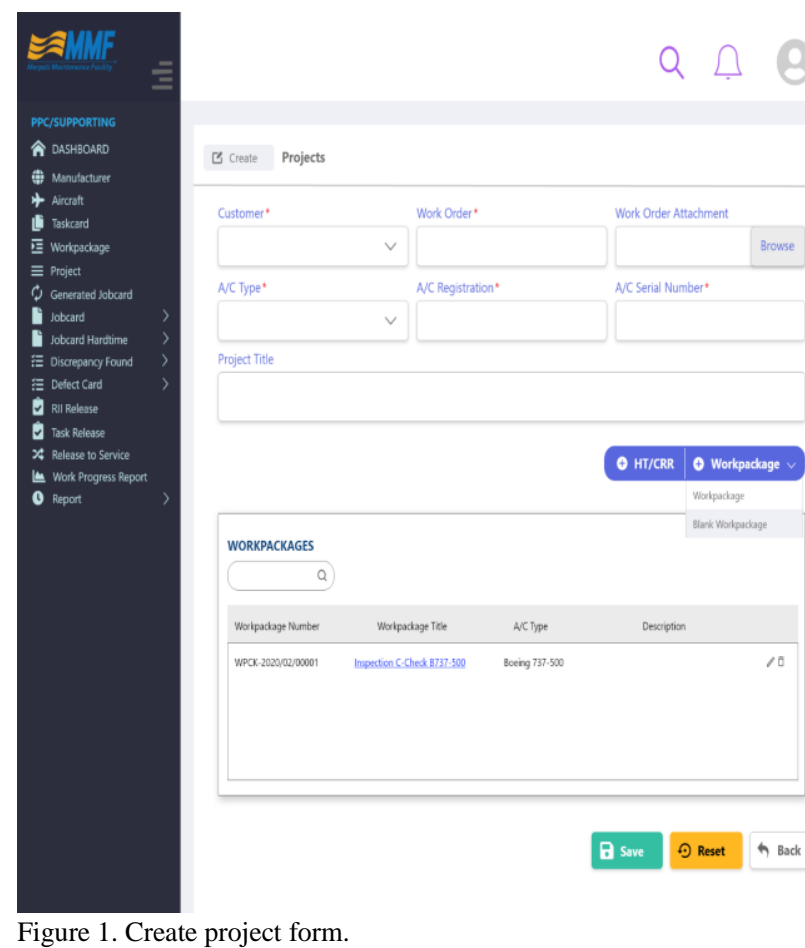

International Aviation Federation, such as the European Aviation Safety Agency (EASA). The vital aspects of aircraft maintenance, among others, are the engineers involved in the maintenance process and the man hours calculation system that must be able to explain every detail of the work on a single aircraft maintenance project.

Engineer is a major resource in aircraft maintenance that has expertise in specific areas, such as: Airframe, powerplant, electrical, radio, instrument. In fact, these areas of expertise are still categorized by type/type of aircraft, such as: Boeing 737-200, 737-300, 737-400, 737-500, and others. Engineers can only do the work in accordance with the skills and license owned, so there must be control that can set and restrict this.

The man hours in aircraft maintenance should also be monitored accurately because man hours are the defining aspect of cost calculation and one aspect that determines the size of the quality of the aircraft maintenance work. In a routine aircraft maintenance project, the breakdown of job details that must be done can reach thousands, and from each job the man hours must also be accurately recorded until the aircraft maintenance process has been completed. The man 
The $6^{\text {th }}$ International Seminar on Science and Technology (ISST) 2020

July $25^{\text {th }}$, 2020, Institut Teknologi Sepuluh Nopember, Surabaya, Indonesia

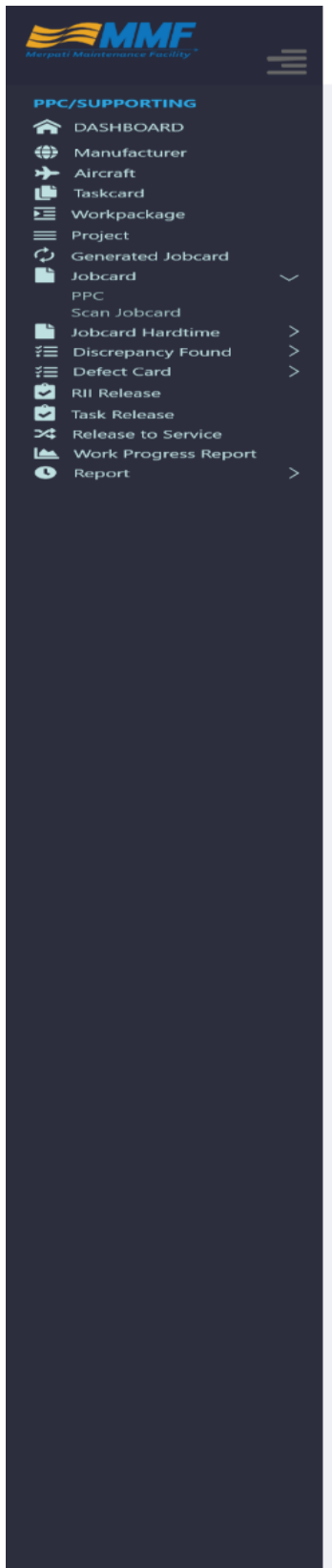

Figure 2. Jobcard process.

hours of the work should then be counted to know the total man hours in one aircraft maintenance project. This Man hours can also be a reference to figure out the extent to which the progress of an aircraft maintenance project has been conducted. So that man hours is a vital aspect that must be monitored in actuals, and can assist top level management in determining aircraft maintenance business strategy.

The cost of goods sold (COGS) or the price in a aircraft maintenance project is also highly determined by the use of consumable material and raw material during the project, so there must be a planning, management, and control over the entire use of materials. Measured HPP, will greatly affect the top level management in determining the sales price strategy to the customer, of course it aims to find a selling price that maximizes profit for the company.

Based on the need for monitoring and controlling aspects of job restrictions by engineers and man hours aspect to other resources used during the aircraft maintenance process, it is necessary to implement an IT-based system that can help project leader/planner and top level management to determine the good strategy in aircraft maintenance.

\section{METHOD}

\section{A. Basic concepts of system development}

System development can be interpreted as a standardized development process defining a set of activities, methods, best practices, ready-delivered goods, and automated devices that will be used by system developers and project managers to develop and continuously improve information systems and software (Indrajit, 2002).

\section{B. Basic principles of system development}

The development of information systems is as an activity to generate computer-based information systems to solve organizational problems or problems or to take advantage of 


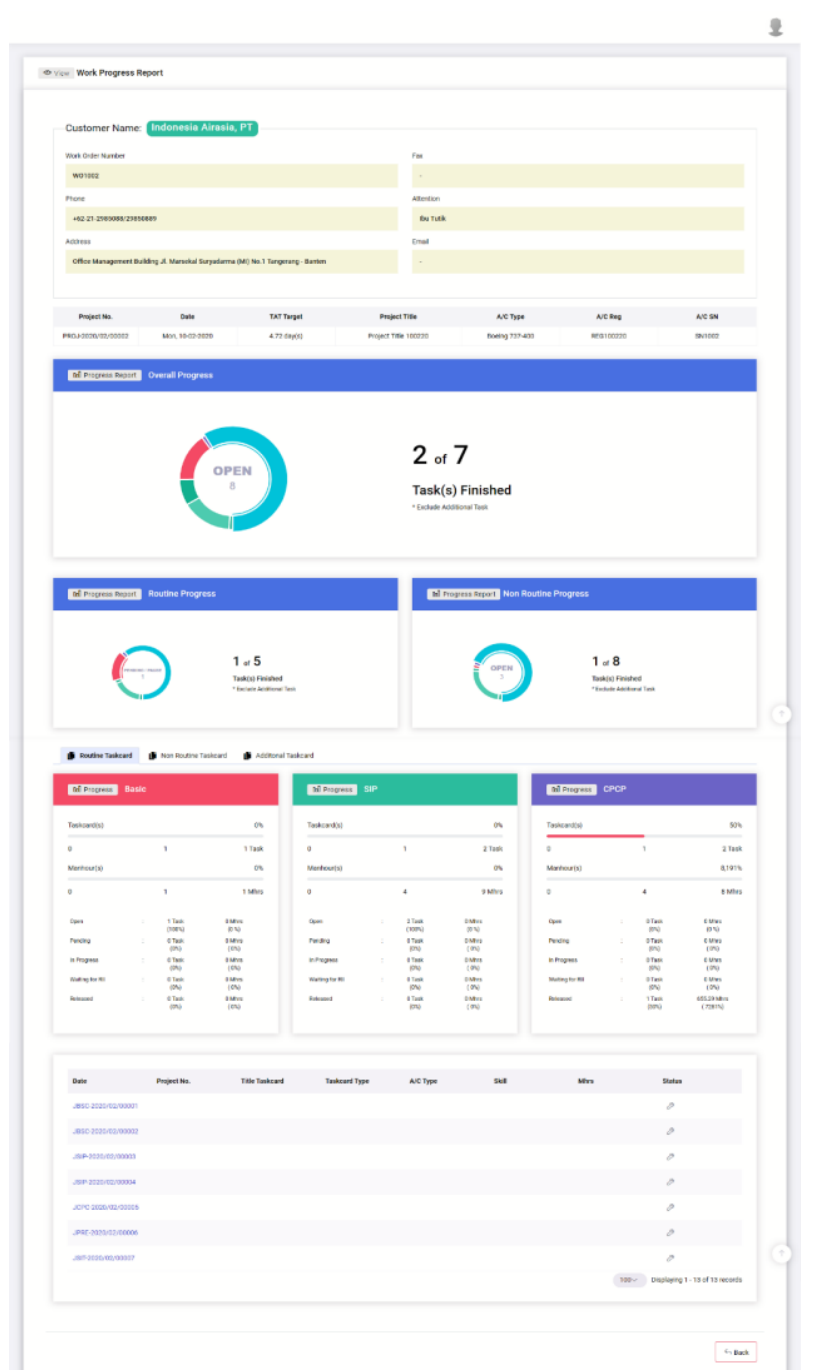

Figure 3. Work progress report.

opportunities that occur. As for some basic principles of development of other between systems (Indrajit, 2002):

1. Owners and users of the system must engage

2. Using a troubleshooting approach

3. Determining the stages of development

4. Set the standard for consistent development and documentation

5. Don't be afraid to cancel or change the work environment

6. Solving problems into small parts

7. Designing the system for growth and development

\section{System Development Life Cycle (SDLC)}

The System Development Life Cycle (SDLC) is a classical methodology used to develop, maintain and use information systems [1]. Since the work follows a sequential pattern and is done with the top down method, SDLC is often known as a waterfall approach. The activity stream runs one way from the beginning until the project is completed.

\section{1) Policies and Planning System}

The system planning process aims to plan system projects that will be developed later. Doing this system planning process is a system planning staff (planning staff) who consult with the Steering Committee. The system planning process consists of the following stages:

1. Assess the purpose of making systems

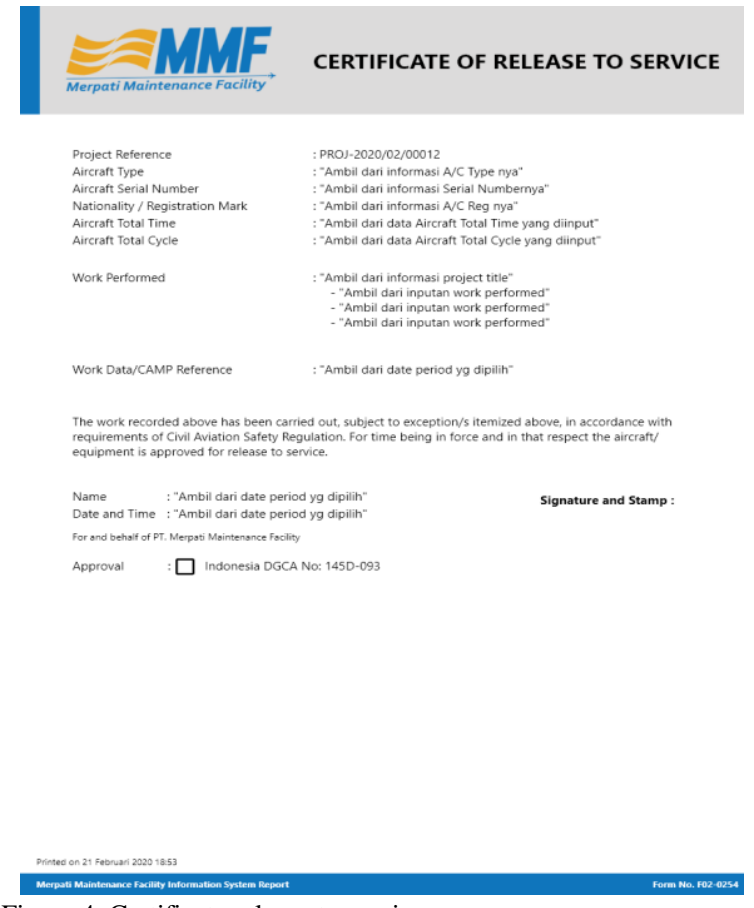

Figure 4. Certificate release to service.

2. Identifying System Projects

3. Set a system goal to be created

4. Observe the constraints that occur during system creation 2) Analysis System

The analysis stage is the parser of an intact information system into parts of its components with a view to identifying and evaluating the problems, opportunities, obstacles and expected needs so that it can be proposed Perbaikanperbaikannya.

\section{3) Design System}

System design can be divided into two parts, namely system design in general also called logical design, and detailed system design is also called by physical system design.

1. System Design in general. The purpose of the system design in general is to give the user a general picture of the new system. System design in general merfodder preparation of detailed design.

2. Detailed system Design. This stage is a more detailed explanation of the design that is in the previous stage.

4) Selection System

This stage is a select stage of hardware and software for information systems.

\section{5) Implementation System}

The system implementation stage is the level of laying system ready to operate. This stage also includes writing program code.

\section{RESULT AND DISCUSSION}

Before designing and technical design is done, then based on the results of analysis of existing business process, do some changes, and the expected business processes, among others are: 


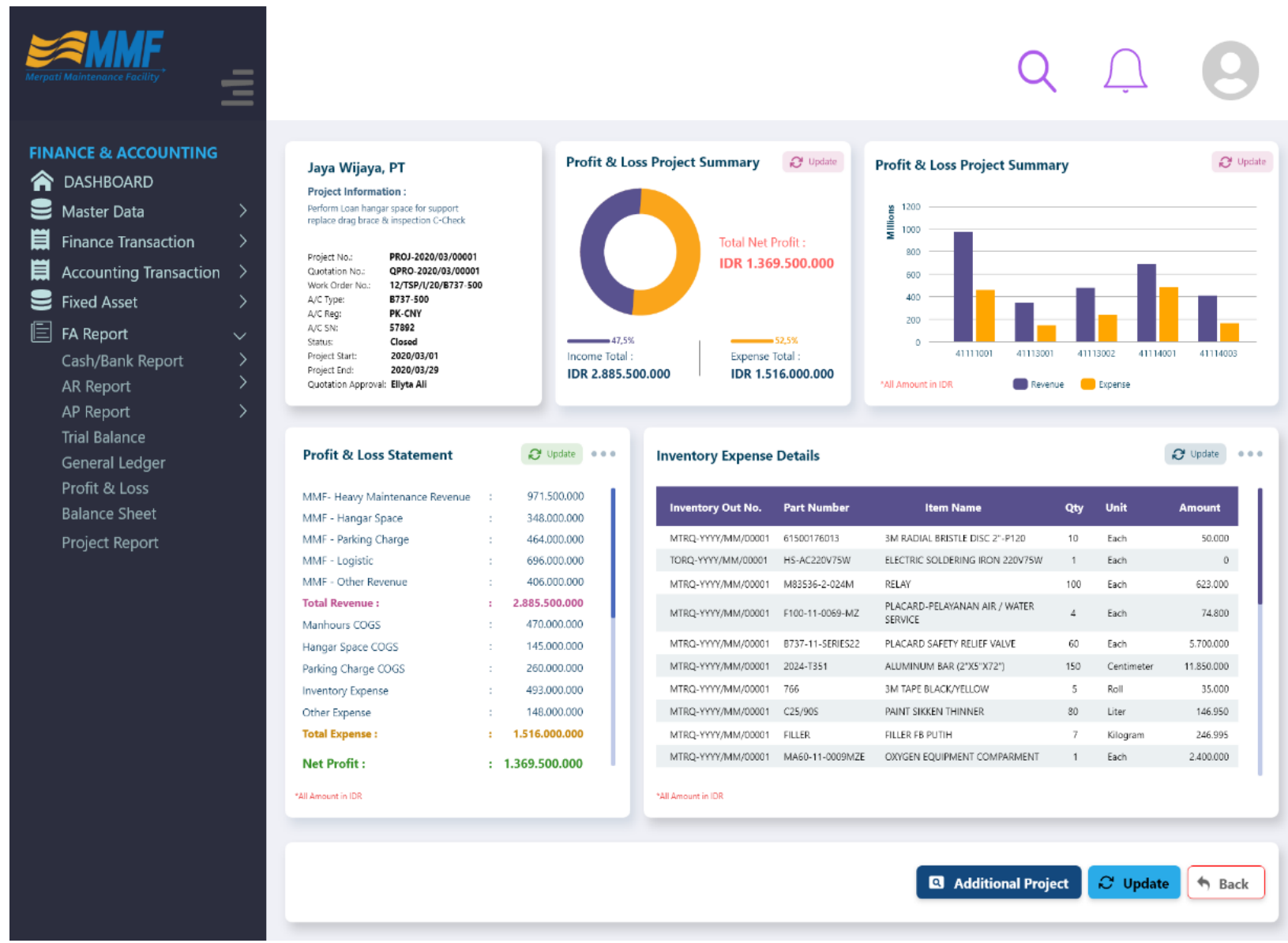

Figure 5. Profit and loss project.

\section{A. Process of creating projects}

Is a process that serves to make planning for the process of aircraft maintenance work that contains data taskcard, calculation manhours, usage facilities, until the determination of a dedicated team. Create prohect form can see at Figure 1.

\section{B. Jobcard Process}

This jobcard process serves to perform the execution process or to start the work that will be done by mechanics and engineers. This Form displays all information of the Jobcard data, among others is the skill information, estimation manhours, work area or the location of the work area, to the description of the work to be done as well as the needs of materials and tools needed to work on the work. This process can only be done by an engineer who has a special license in aircraft maintenance. Jobcard process can see at Figure 2.

\section{Work Progress Report}

This work progress report serves to display the ongoing progress information of the work. This Form contains information about ongoing project data and all job progress details, making it easier for the supporting team to monitor the progress of the work being done by mechanics and engineers. Work progress report can see at Figure 3.

\section{Release To Service}

Release To Service Certificate is a certificate issued by the MRO company as the basis for the completion of the aircraft maintenance repair process as well as authorizing that the aircraft is eligible to fly after the repair process is complete. Certificate release to service can see at Figure 4.

\section{E. Profit and Loss Project}

The Profit and Loss, also called Income, is probably the most important and most common of the three essential projections in standard business plan financials. Tracking profits and loss requires detailed records of project-related income and expenses. Profit and loss project can see at Figure 5 .

\section{CONCLUSION}

The conclusions of the results of this study are Design of Resources Monitoring and Controlling System on Aircraft Maintenance Project In XYZ MRO can control/authorize control of any work performed based on the area of expertise.

Design of Resources Monitoring and Controlling System on Aircraft Maintenance Project In XYZ MRO can control the distribution and use of consumable material and raw material when the aircraft maintenance project is in progress.

Design of Resources Monitoring and Controlling System on Aircraft Maintenance Project In XYZ MRO can provide realtime reports or reporting on all key resource movements such as: Manhours of engineer, status of each task or occupation in aircraft maintenance projects, and comparison between estimation/planning of manhours with actual running manhours. 
The $6^{\text {th }}$ International Seminar on Science and Technology (ISST) 2020

July $25^{\text {th }}, 2020$, Institut Teknologi Sepuluh Nopember, Surabaya, Indonesia

\section{REFERENCES}

[1] Jogiyanto, H.M, Pengenalan Komputer. Yogyakarta: Andi Offset.1985 Jogiyanto, Hartono, MBA.Ph.D. Analisis dan Desain Sistem Informas Pendekatan Terstruktur teori dan Praktek Aplikasi Bisnis. Yogyakarta: Andi. 2005

[2] MMF, 2019, SKEP Direktur Utama, Surabaya

[3] Merpati, 2010, AMOQC (Aircraft Maintenance Organization Quality Control) Procedure, Jakarta.
[4] Merpati, 2010, MOE (Maintenance Organization Exposition) Procedure, Jakarta.

[5] MMF, 2019, Minutes of Meeting (Business Process Test), Surabaya.

[6] Romeo, 2003. Testing dan Implementasi Sistem, Edisi Pertama, Surabaya: STIKOM Surabaya.

[7] Qantas Airlines Press Release, 2016, The A, C, D of Aircraft Maintenance, Australia. https://www.qantasnewsroom.com.au/rootales/the-a-c-and-d-ofaircraft-maintenance/

[8] Shanti, Ida Ayu Prima, 2005. Jurnal: Menjelaskan Konsep Dasar IMK. 